\title{
The demands of family caregivers of elderly individuals with dementia
}

DEMANDA DO CUIDADOS FAMILIAR COM IDOSO DEMENCIADO

DEMANDAS DEL CUIDADOR FAMILIAR DEL ANCIANO CON DEMENCIA

\begin{abstract}
Aline Cristina Martins Gratao ${ }^{1}$, Francisco de Assis C. do Vale ${ }^{2}$, Matheus Roriz-Cruz ${ }^{3}$, Vanderlei José Haas $^{4}$, Celmira Lange ${ }^{5}$, Luana Flávia da Silva Talmelli' ${ }^{6}$, Rosalina Aparecida Partezani Rodrigues ${ }^{7}$
\end{abstract}

\begin{abstract}
The purpose of this cross-sectional observational study was to identify characteristics of caregivers of elderly people with dementia, types of care demands and to relate demands to the stage of dementia. The study was carried out in 2004 with 104 older adults and 90 caregivers in Ribeirão Preto, state of São Paulo. The OARS instrument was utilized and a questionnaire answered by caregivers. Among older adults, $66.3 \%$ were female, aged 75.5 years in average and $86.5 \%$ had caregivers. Eighty percent of the caregivers were women family members, aged 52.3 years in average. They spent 15.10 hours/day with care, without help. An important relationship was observed between caregiver's burden, physical and emotional effort and stage of dementia. Emotional overburden was higher at dementia early and late stages, this difference was statistically non-significant. Results reveal the urgent need to plan formal and informal support strategies to caregivers of Brazilian elderly people with dementia.
\end{abstract}

\section{KEY WORDS}

Aged.

Dementia.

Caregivers.

\section{RESUMO}

As finalidades deste estudo foram identificar as características dos cuidadores de idosos demenciados, os tipos de demandas de cuidados e relacionar a demanda com o estágio da demência. $O$ estudo seccional e observacional foi conduzido em 2004, com 104 idosos e 90 cuidadores, em Ribeirão Preto/SP, por meio do instrumento OARS e de um questionário para o cuidador. Dos 104 idosos, $66.3 \%$ eram mulheres, a idade média de 75.5 anos, sendo que $86.5 \%$ deles tinham cuidadores. Entre os cuidadores, $80 \%$ eram mulheres, membros da família, com idade média de 52.3 anos. Dedicavam 15.10 horas/dia para a atividade de cuidar, sem nenhuma ajuda. Encontrou-se importante relação entre a sobrecarga do cuidador, o esforço físico e emocional, e o estágio da demência. A sobrecarga emocional foi maior nos estágios iniciais e tardios da demência, mas a diferença foi estatisticamente não-significante. Os resultados atuais revelam a urgente necessidade de planejar estratégias de suporte formal e informal para cuidadores de idosos brasileiros com demência.

\section{DESCRITORES}

Idoso.

Demência.

Cuidadores.

\section{RESUMEN}

La finalidad de este estudio fue identificar características de los cuidadores de ancianos con demencia, tipos de demanda de cuidados y relacionar la demanda con el estadio de la demencia. Este estudio seccional y observacional fue efectuado en 2004 con 104 ancianos y 90 cuidadores en Ribeirão Preto/SP/Brasil, a través del instrumento OARS y un cuestionario para el cuidador. De los 104 ancianos, 66,3\% eran mujeres, la edad media fue de 75,5 años y $86,5 \%$ del total tenían cuidadores. Entre los cuidadores, $80 \%$ eran mujeres, miembros de la familia, con edad media de 52,3 años. Dedicaban 15,10 horas/día para la actividad de cuidar, sin ayuda ninguna. Se encontró una importante relación entre la sobrecarga del cuidador, el esfuerzo físico y emocional y el estadio de la demencia. La sobrecarga emocional resultó mayor en los estadios iniciales y tardíos de la demencia, esta diferencia no fue estadísticamente significativa. Los resultados actuales revelan la necesidad urgente de planear estrategias de soporte formal e informal para cuidadores de ancianos brasileños con demencia.

\section{DESCRIPTORES}

Anciano.

Demencia.

Cuidadores.

${ }^{1}$ MSC in the Graduate Program on Fundamentals of Nursing, University of São Paulo at Ribeirão Preto, College of Nursing. Ribeirão Preto, SP, Brazil. alinegratao@eerp.usp.br ${ }^{2}$ MD, PhD, Coordinator of the Behavioral Neurology Group at Hospital das Clínicas, University of São Paulo at Ribeirão Preto, Medical School. Ribeirão Preto, SP, Brazil. facvale@hcrp.fmrp.usp.br ${ }^{3} \mathrm{MD}$, PhD. Department of Internal Medicine."Hospital de Clínicas de Porto Alegre". Brazilian Federal University - Rio Grande do Sul. Porto Alegre, RS, Brasil. cruz@hcpa.ufrgs.br ${ }^{4}$ PhD in Applied Physics, Medicine and Biology. Professor, University of São Paulo at Ribeirão Preto, College of Nursing. Ribeirão Preto, SP, Brazil.haas@eerp.usp.br ${ }^{5}$ PhD in Gerontological Nursing. Professor of Federal University of Pelotas, School of Nursing. Pelotas, RS, Brazil.celmira_lange@ufpel.tche.br ${ }^{6}$ Master Student, Graduate Program on Fundamentals of Nursing, University of São Paulo at Ribeirão Preto, College of Nursing. Ribeirão Preto, SP, Brazil. luanatalm@yahoo.com.br ${ }^{7}$ Full Professor, University of São Paulo at Ribeirão Preto, College of Nursing, Department of General and Specialized Nursing. Ribeirão Preto, SP, Brazil. rosalina@eerp.usp.br

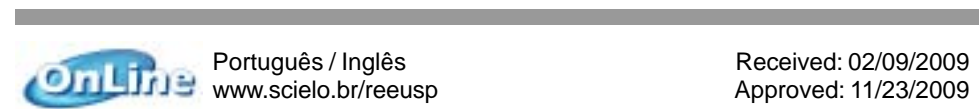




\section{INTRODUCTION}

Population aging was initially observed in highly developed nations with equally high levels of social and health care resources. However, an even more rapid growth in the elderly segment of the population is now occurring in lower-resourced, medium-income developing countries such as Brazil. It is estimated that between the 1980 and 2020, the world's elderly population will grow by $160 \%$, from 375 to 975 million. Around $80 \%$ of this grow will take place in low-resource countries ${ }^{(1)}$. In Brazil, the prediction is for an increase of $280 \%$ in the elderly population, jumping from 7.5 to almost 30 million over the same period. In 1960, Brazil had the $16^{\text {th }}$ largest elderly population in the world. Estimates indicate that, by 2020, Brazil will have the $6^{\text {th }}$ largest elderly population in the world(2).

The physiological aging process may result in a predisposition for non-transmittable chronic diseases. An elderly person with a chronic morbidity leading to incapacity may be a cause of family readjustment. This readjustment may influence families and, especially, a family caregiver, adversely. Data from the World Health Organization (WHO) ${ }^{(3)}$ indicates that the most important chronic diseases affecting elderly people around the world are: arterial hypertension and other cardiovascular diseases, stroke, diabetes mellitus, tumors, chronic obstructive pulmonary disease, musculoskeletal diseases (such as osteoarthrosis and osteoporotic fractures), neuropsychiatric diseases (chiefly dementia and depression), and visual impairment. Among all the above comorbities, dementia may be considered one of the most debilitating, leading to diminished capacity and increased demands for care among the elderly ${ }^{(4)}$.

In analyzing studies on the prevalence of dementia in various regions of the world, the mean prevalence of dementia among individuals over 65 years of age ranged from $2.2 \%$ in Africa to $5.5 \%$ in Asia, $6.4 \%$ in North America, $7.1 \%$ in South America and 9.4\% in Europe. In all regions, except for East Asia, prevalence of the disease was higher among females, and Alzheimer's disease was present more frequently than vascular dementia ${ }^{(5)}$.

Dementia is characterized by progressive loss of cognitive function, which disrupts the individuals' ability to work and/or live in society ${ }^{(6)}$. Initially, individuals demonstrate loss of memory related to recent events and a diminished capacity for concentration. Following this, they usually display losses in spatial orientation, ability to uncover information, and make judgments. This is followed by difficulty in using language and abstract reasoning. Behavioral changes may emerge as the dementia progresses. Symptoms such as anxiety, depression, multiple physical complaints, sleep disturbances, restlessness, irritability, emotional instability, changes in behavioral patterns, aggressiveness, psychomotor agitation, illusions, hallucination, delirium and inappropriate sexual behavior may be observed ${ }^{(6)}$.
As dementia evolves, it may cause deficits in the individuals' functional capacity that lead to a progressive loss of autonomy and independence, thereby leading to dependence for performing basic Activities of Daily Living (ADLs). For elderly people with dementia, thus, their families often need to take on the responsibility for their care at home. That is, the relatives become the caregivers. This function is usually performed by one family member who lives with the demented elderly person and who, with little or almost no guidance or training, provides care that is essential for maintaining the elderly individual's (quality of) life.

The activity of taking care of demented individuals may result in overloading a caregiver's life. Behavioral disorders in people with dementia may contribute to depression, anxiety and deterioration in the physical condition of their caregivers $^{(7)}$. Providing care at home through nursing is a fundamental activity, as well as an activity related to security, thus for the caregiver it could elicit feelings like fear, anxiety and doubts about how to care without undermining the quality of the care provided ${ }^{(7-8)}$.

Family caregivers are often inadequately prepared, lack knowledge or support for taking on this role. This means that, although they try to provide care by using their own resources, their often mixed feelings of love, duty and repressed anger come to make up an informal care system in which exhaustion and stress prevail. Under this situation, the well-being and mental health of the family as a whole might deteriorate.

Therefore, it is important to develop strategies for improving the provision of the needs for both the elderly demented individual and his/her relative-caregiver. Obtaining data on family caregiving for elderly demented people may be fundamental in allowing a better understanding of the problems experienced by the family and, thus, providing adequate interventional measures for this population.

Therefore, the present study was developed to answer the following questions: What types of care do elderly individuals with dementia in Brazil require? Which are the demands for care from the demented individuals, in relation to the stage of their dementia? Who are the caregivers for demented elderly individuals in Brazil, and how is the care process undertaken in the different stages of dementia?

\section{OBJECTIVES}

- Characterize the demented elderly individuals;

- Characterize caregivers in regard to their social profiles, knowledge of the caring process, dedication to caring activities, self-consequences from this care, and the formal and informal support for this care;

- Evaluate the demands for care that were placed on the caregivers due to these demented elderly subjects, according to the stage of dementia. 


\section{METHOD}

This study used a cross-sectional epidemiological design. The study population included all demented elderly ( $\geq 60$ years) patients (and their caregivers) who were treated at the behavioral neurology outpatient clinic of the (public) University Hospital of the University of São Paulo at Ribeirão Preto, SP, Brazil during 2003 and 2004. Ribeirão Preto is a city with about 550,000 inhabitants in the countryside of the state of São Paulo.

Medical records of these demented elderly individuals were analyzed in order to identify the sample. Identification data, address, telephone number and medical diagnosis were extracted from these records. Among the 154 elderly who were patients at the clinic, 50 (32.4\%) were excluded: $28(56 \%)$ due to death, 11 (22\%) because of changed address, $6(12 \%)$ because they were classified as healthy according to the Clinical Dementia Rating ${ }^{(9)}(\mathrm{CDR})$ and had not been classified by CDR scale in 2004 and 5 (10\%) because they refused to participate in the research.

In order to collect the data, the following instruments were utilized:

\section{Older Americans Resources and Services (OARS) ${ }^{(10)}$ : characterization of the demented elderly subjects}

The items of the instrument utilized were composed of two items:

1 - Identification: gender, age and marital status;

2 - Social profile of the elderly individual: level of schooling, socioeconomic status.

\section{Clinical Dementia Rating (CDR)}

The state of dementia had already been assessed by the medical team by means of the Clinical Dementia Rating (CDR) in 2004, as described on the patient's medical records. The CDR was validated for Portuguese in $2005^{(9)}$. It allows researchers to classify the prevalence of the diverse degrees of dementia, beyond identifying questionable cases (those that do not fit in the normal definition).

\section{Instrument for characterization of the caregiver (ICC)}

Allowed the following characteristics to be determined: gender, age, marital status, degree and nature of the relationship with the patient, knowledge of the disease, whether the person had taken any formal course on caring, the number of hours dedicated to caring, consequences and activities of caring, and support from other people. This instrument was drawn up by the investigators and submitted to four specialists in the field for analysis. The final version of the instrument was made by consensus.

Data were collected through interviews with the demented elderly individuals and their caregivers at their own home. All patients, the elderly individual and the caregivers, gave informed consent. The Research Ethics Committee at the University Hospital of the University of São Paulo at Ribeirão Preto approved the study (process HCRP number 2929/2003). Each interview lasted on average one hour. Data were collected between January and June 2004 and were subsequently analyzed through univariate and bivariate descriptive statistics (contingency tables) utilizing the Statistical Package for the Social Sciences (SPSS, 1999) program.

\section{RESULTS}

\section{Characterization of elderly individuals with dementia}

One hundred and four (104) elderly individuals with a diagnosis of dementia were evaluated. There were 69 women (66.3\%) and 35 men (33.7\%). Their ages ranged from 63 to 91 years, with a mean of $75.5( \pm 7)$ years. The largest age category was represented by elderly patients between $75-79$ years old (26.4\%). Sixty-two (62.3\%) elderly women patients were widows, while $82.8 \%$ of their male counterparts were married.

As for schooling, 20 (19.2\%) were illiterate, 17 (16.3\%) learned to read only through unofficial means (mainly at home), 49 (47.1\%) attended school for one to four years, $10(9.6 \%)$ studied for five to eight years, three $(2.9 \%)$ for nine to twelve years, and another three $(2.9 \%)$ for more than 13 years (undergraduate level), as shown in Table 1.

Table 1 - Distribution of demented elderly individuals treated by the behavioral neurology outpatient clinic of the university hospital, University of São Paulo at Ribeirão Preto, Medical School, according to the age group, sex, marital status and educational level - Ribeirão Preto - 2004

\begin{tabular}{|c|c|c|c|c|c|c|}
\hline \multirow{2}{*}{$\begin{array}{l}\text { Social profile } \\
\text { of the elderly } \\
\text { individual }\end{array}$} & \multicolumn{2}{|c|}{ Female } & \multicolumn{2}{|c|}{ Male } & \multicolumn{2}{|c|}{ Total } \\
\hline & $\mathbf{N}$ & $\%$ & $\mathbf{N}$ & $\%$ & $\mathbf{N}$ & $\%$ \\
\hline \multicolumn{7}{|l|}{ Age group (years) } \\
\hline $60-64$ & 2 & 2.9 & 4 & 11.4 & 6 & 5.8 \\
\hline $65-69$ & 15 & 21.78 & 7 & 20.0 & 22 & 21.2 \\
\hline $70-74$ & 12 & 17.4 & 6 & 17.1 & 18 & 17.3 \\
\hline $75-79$ & 16 & 23.2 & 10 & 28.6 & 26 & 25.0 \\
\hline $80-84$ & 14 & 20.3 & 6 & 17.1 & 20 & 19.2 \\
\hline $85+$ & 10 & 14.5 & 2 & 5.7 & 12 & 11.5 \\
\hline \multicolumn{7}{|l|}{ Marital status } \\
\hline Single & 5 & 7.2 & 1 & 2.9 & 6 & 5.8 \\
\hline Married & 17 & 24.6 & 29 & 82.8 & 46 & 44.2 \\
\hline Divorced & 4 & 5.8 & 2 & 5.7 & 6 & 5.8 \\
\hline Widow(er) & 43 & 62.3 & 3 & 8.6 & 46 & 44.2 \\
\hline \multicolumn{7}{|l|}{ Educational level } \\
\hline Illiterate & 16 & 23.2 & 4 & 11.4 & 20 & 19.2 \\
\hline $\begin{array}{l}\text { Literate but no } \\
\text { formal education }\end{array}$ & 14 & 20.3 & 3 & 8.6 & 17 & 16.3 \\
\hline $1-4$ years & 30 & 43.5 & 19 & 54.3 & 49 & 47.1 \\
\hline $5-8$ years & 6 & 8.7 & 4 & 11.4 & 10 & 9.6 \\
\hline $9-12$ years & 2 & 2.9 & 1 & 2.8 & 3 & 2.9 \\
\hline$\geq 13$ years & 1 & 1.4 & 2 & 5.7 & 3 & 2.9 \\
\hline Total & 69 & 66.3 & 35 & 33.7 & 104 & 100 \\
\hline
\end{tabular}

Note: $(n=104)$ 


\section{Characterization of the caregiver}

Among the 104 elderly individuals, 90 (86.5\%) had caregivers and, of these, 64 (80\%) were female. Most (90\%) caregivers were family members, i.e. wife, daughter or daughter-in-law, with a mean age of 52.3 years ( \pm 13.5 ). There were 16 male caregivers (20\%), who were mostly husbands (82\%), with a mean age of 64.6 years ( \pm 11.2 ).

With regard to the caregiver's self-perceived knowledge about the elderly subject's disease, eight (8.9\%) said they had little and insufficient knowledge for caregiving, 22 (24.4\%) said they had little knowledge but it was sufficient, $39(43.3 \%)$ answered they had good knowledge, and 21 $(23.3 \%)$ alleged they were very well-informed about the disease. Only 17 (19.1\%) have participated in a formal course regarding knowledge for caregiving. The mean daily length of time dedicated for caring for the elderly individual was 15.10 hours.

With regard to the assistance that the caregiver received for dealing with the demented person's ADLs (body hygiene, oral hygiene, evacuations, skin care, feeding, medication, sleep/rest, physical activity, leisure and return consultations), the item for which no assistance was most reported (47.7\%) was, as expected, sleep/rest. Physical activity and return consultations were next (44.4\%). The activities for which assistance always/almost always received was most reported were return consultations (30\%), feeding (25.5\%), and medication and body hygiene ( $24.4 \%$ for both; see Table 2 ).

Table 2 - Self-reported assistance received by caregivers according to the type of activity of daily living performed - Ribeirão Preto - 2004

\begin{tabular}{|c|c|c|c|c|c|c|c|c|c|c|c|}
\hline \multirow{2}{*}{$\begin{array}{l}\text { Assistance received by } \\
\text { caregivers by type of } \\
\text { activity of daily living } \\
\text { Receives help for: } \\
\end{array}$} & \multicolumn{2}{|c|}{ No } & \multicolumn{2}{|c|}{ Sometimes } & \multicolumn{2}{|c|}{ Always } & \multicolumn{2}{|c|}{$\begin{array}{l}\text { Does not } \\
\text { apply* }\end{array}$} & \multicolumn{2}{|c|}{ Total } & \multirow{2}{*}{$\begin{array}{c}\begin{array}{c}\text { Pearson } \\
\text { Chi-Square }\end{array} \\
\text { P-value } \\
\end{array}$} \\
\hline & $\mathbf{N}$ & $\%$ & $\mathbf{N}$ & $\%$ & $\mathbf{N}$ & $\%$ & $\mathbf{N}$ & $\%$ & $\mathbf{N}$ & $\%$ & \\
\hline Body hygiene & 23 & 25.6 & 27 & 30 & 22 & 24.4 & 18 & 20 & 90 & 100 & 0.747 \\
\hline Oral hygiene & 33 & 36.6 & 20 & 22.2 & 19 & 21.1 & 18 & 20 & 90 & 100 & 0.079 \\
\hline Evacuations & 36 & 40 & 0 & 22.2 & 18 & 20 & 16 & 17.8 & 90 & 100 & 0.014 \\
\hline Skin care & 38 & 42.2 & 22 & 24.4 & 14 & 15.5 & 16 & 17.8 & 90 & 100 & 0.002 \\
\hline Feeding & 35 & 38,8 & 23 & 25.6 & 23 & 25.5 & 9 & 10 & 90 & 100 & 0.169 \\
\hline Medication & 33 & 36.6 & 26 & 28.9 & 22 & 24.4 & 9 & 10 & 90 & 100 & 0.317 \\
\hline Sleep/rest & $\underline{43}$ & 47.7 & 18 & 20 & 14 & 15.5 & 15 & 16.7 & 90 & 100 & 0.000 \\
\hline Physical activities & $\overline{40}$ & $\overline{44.4}$ & 15 & 16.7 & 9 & 10 & 26 & 28.9 & 90 & 100 & 0.000 \\
\hline Leisure & 36 & 40 & 15 & 16.7 & 15 & 16.7 & 24 & 6.6 & 90 & 100 & 0.001 \\
\hline Return consultations & 40 & 44.4 & 19 & 21.1 & $\underline{27}$ & $\underline{30}$ & 3 & 1.1 & 90 & 100 & 0.020 \\
\hline
\end{tabular}

* Does not apply means that the caregiver does not need to execute this activity for the elderly, because the elderly can do it alone.

To be engaged in any kind of group activity was an uncommon condition for caregivers - the church being the most reported group (11.1\%).

\section{Identification of demented elderly subjects' demands for care placed upon their caregivers}

Among the ADLs which were most exhausting for caregivers, helping the demented elderly individual to have baths and with body hygiene was reported the most. The activity that caused the least physical tiredness was assistance in feeding. With regard to emotional stress, it was observed that the patient's behavior was what caused the greatest impact on the caregiver's emotional status.

In accordance with the stage of the dementia, among the 104 elderly individuals studied, 29 (27.9\%) presented severe dementia; 23 (22.1\%), moderate; 29 (27.9\%), mild; and seven (6.7\%), borderline. Sixteen (15.4\%) had not been assessed by this method, i.e. there was no information on the degree of dementia in their medical records, but only the diagnosis of dementia.

Among these 104 elderly subjects, 14 (13.5\%) did not have caregivers and, among these, three $(21.4 \%)$ had moderate-stage dementia, six $(42.85 \%)$ mild, four (28.6\%) borderline, and one (7.1\%) no assessment via CDR.
The etiologies of the dementing process, as identified from the patients' medical records, are shown in Table 3. Alzheimer's disease was the most common presumptive diagnosis.

Table 3 - Distribution of the etiologies of dementia among the elderly individuals treated by the behavioral neurology outpatient clinic of the teaching Hospital of Ribeirão Preto Medical School, University of São Paulo - Ribeirão Preto - 2004

\begin{tabular}{lcc}
\hline Etiology & N & $\mathbf{~ \% ~}$ \\
\hline Alzheimer's disease alone & 44 & 42.3 \\
Alzheimer dementia with vascular dementia & 11 & 10.6 \\
Vascular dementia alone & 10 & 9.6 \\
Dementia caused by alcohol use & 8 & 7.7 \\
Depression & 7 & 6.7 \\
Parkinson's disease & 6 & 5.8 \\
Normal pressure hydrocephalus & 3 & 2.9 \\
Lewy body dementia & 3 & 2.9 \\
Frontotemporal dementia & 2 & 1.9 \\
Cancer of the central nervous system & 2 & 1.9 \\
Unknown etiology & 8 & 7.7 \\
\hline Total & $\mathbf{1 0 4}$ & $\mathbf{1 0 0}$ \\
\hline
\end{tabular}

Associative analysis of the data on the physical and emotional exhaustion items reported by the caregivers were analyzed by stage of the dementia (mild, moderate and severe). As expected, this analysis showed that these 
symptoms were, for most tasks, more prevalent in the severe stage of dementia (bathing/hygiene, dressing, tak-

ing the patient for consultations, and behavior control) (Table 4).

Table 4 - Prevalence of overburden of caregiver according to type of physical and emotional stressor and the staging of dementia Ribeirão Preto - 2004

\begin{tabular}{|c|c|c|c|c|c|c|c|c|c|}
\hline \multirow{3}{*}{$\begin{array}{l}\text { Prevalence of overburden by type } \\
\text { of stressor }\end{array}$} & \multicolumn{8}{|c|}{ Stage of dementia } & \multirow{3}{*}{$\begin{array}{l}\text { Pearson } \\
\text { Chi-Square }\end{array}$} \\
\hline & \multicolumn{2}{|c|}{ Mild } & \multicolumn{2}{|c|}{ Moderate } & \multicolumn{2}{|c|}{ Severe } & \multicolumn{2}{|c|}{ Total } & \\
\hline & $\mathbf{N}$ & $\%$ & $\mathbf{N}$ & $\%$ & $\mathbf{N}$ & $\%$ & $\mathbf{N}$ & $\%$ & \\
\hline $\begin{array}{c}\text { Feeding } \\
\text { Physically overburdened? }\end{array}$ & & & & & & & & & 0.703 \\
\hline Yes & 7 & 31.8 & 7 & 31.8 & 8 & 36.4 & 22 & 100 & \\
\hline No & 13 & 28.9 & 11 & 24.4 & 21 & 46.7 & 45 & 100 & \\
\hline Emotionally overburdened? & & & & & & & & & 0.664 \\
\hline Yes & 10 & 35.7 & 6 & 21.4 & 12 & 42.8 & 28 & 100 & \\
\hline No & 11 & 27.5 & 12 & 30.0 & 17 & 42.5 & 40 & 100 & \\
\hline $\begin{array}{c}\text { Bathing/hygiene } \\
\text { Physically overburdened? }\end{array}$ & & & & & & & & & 0.666 \\
\hline Yes & 10 & 26.3 & 10 & 26.3 & 18 & 47.4 & $\underline{38}$ & 100 & \\
\hline No & 9 & 31.0 & 9 & 31.0 & 11 & 37.9 & 29 & 100 & \\
\hline Emotionally overburdened? & & & & & & & & & 0.824 \\
\hline Yes & 9 & 27.3 & 9 & 27.3 & 15 & 45.5 & 33 & 100 & \\
\hline No & 12 & 33.3 & 10 & 27.8 & 14 & 38.9 & 36 & 100 & \\
\hline $\begin{array}{c}\text { Dressing } \\
\text { Physically overburdened? }\end{array}$ & & & & & & & & & 0.967 \\
\hline Yes & 9 & 31.0 & 8 & 27.6 & 12 & 41.4 & 29 & 100 & \\
\hline No & 11 & $28 . .2$ & 11 & 28.2 & 17 & 43.6 & 39 & 100 & \\
\hline Emotionally overburdened? & & & & & & & & & 0.503 \\
\hline Yes & 9 & 31.0 & 6 & 20.7 & 14 & 48.3 & 29 & 100 & \\
\hline No & 11 & 28.2 & 13 & 33.3 & 15 & 38.5 & 39 & 100 & \\
\hline $\begin{array}{c}\text { Medicating } \\
\text { Physically overburdened? }\end{array}$ & & & & & & & & & 0.318 \\
\hline Yes & 11 & 42.3 & 7 & 26.9 & 8 & 30.8 & 26 & 100 & \\
\hline No & 12 & 26.1 & 13 & 28.3 & 21 & 45.6 & 46 & 100 & \\
\hline Emotionally overburdened? & & & & & & & & & 0.163 \\
\hline Yes & 13 & 39.4 & 6 & 18.2 & 14 & 42.4 & 33 & 100 & \\
\hline No & 9 & 23.7 & 14 & 36.8 & 15 & 39.5 & 38 & 100 & \\
\hline $\begin{array}{c}\text { Return consultations } \\
\text { Physically overburdened? }\end{array}$ & & & & & & & & & 0.804 \\
\hline$\overline{\text { Yes }}$ & 11 & 36.6 & 8 & 26.6 & 11 & 36.6 & 30 & 100 & \\
\hline No & 12 & 29.3 & 12 & 29.3 & 17 & 41.4 & 41 & 100 & \\
\hline Emotionally overburdened? & & & & & & & & & 0.528 \\
\hline Yes & 12 & 33.3 & 8 & 22.2 & 16 & 44.4 & $\underline{36}$ & 100 & \\
\hline No & 10 & 28.6 & 12 & 34.3 & 13 & 37.1 & 35 & 100 & \\
\hline $\begin{array}{c}\text { Patient's behavior } \\
\text { Physically overburdened? }\end{array}$ & & & & & & & & & \\
\hline Yes & 11 & 31.4 & 11 & 31.4 & 13 & 37.2 & $\underline{35}$ & 100 & 0.779 \\
\hline No & 12 & 32.4 & 9 & 24.3 & 16 & 43.3 & $\overline{37}$ & 100 & \\
\hline Emotionally overburdened? & & & & & & & & & \\
\hline Yes & 11 & 27.5 & 11 & 27.5 & 18 & 45.0 & $\underline{40}$ & 100 & 0.749 \\
\hline No & 11 & 35.4 & 9 & 29.2 & 11 & 35.4 & $\overline{31}$ & 100 & \\
\hline
\end{tabular}

The prevalence of caregiver overburdening was not proportional to the severity of the stage of dementia for all aspects of both the physical and emotional dimensions of this overburdening. Interestingly, however, the emotional overburdened aspect of feeding and dressing, and both the physical and emotional overburdening aspects of medicating and helping in return consultations were lower in the moderate stage of dementia than in both extremes (Table 4).

Feeding' presented significant dissociation between the physical and emotional dimensions of overburdening, according to the stage of dementia, with an important reduc- 
tion in the emotional - but not physical - overburdening in the moderate stage of dementia.

\section{DISCUSSION}

The higher prevalence of females in the elderly population was in accordance with findings from other national and foreign studies on dementia ${ }^{(5,7)}$. This phenomenon may be explained by two facts: (1) women live longer than men and (2) dementia, especially Alzheimer, is more prevalent among elderly women ${ }^{(4)}$.

Women responded for the vast majority of caregivers $(80 \%)$. This is also in accordance with other research conducted in Brazil( ${ }^{(7,11-13)}$ and in other countries ${ }^{(14)}$. In Brazil the role of caring is also culturally and socially attributed to women. First, they care for their children, then for their parents, finally, for their husbands.

The mean age of the caregivers was 52.3 years for women and 64.6 years for men, similar to other studies ${ }^{12,14-}$ 15). In another words, they were within the adult age range in which women have several social roles, such as working outside home, in addition to taking care of their elderly parents and/or husbands.

The higher mean age for male caregivers is in accord with the fact that most males were spouses, as opposed to female caregivers, who are mainly daughters or daughtersin-law. This phenomenon was expected since, also in Brazil, women live longer than men, and, by the age they get dementia, most of them are already widows. Moreover, men usually become functionally dependent at higher ages than women ${ }^{(12)}$.

A lengthy time was devoted to caring for the demented elderly, with a mean of 15.10 hours/day. Similar data were found in other study ${ }^{(14)}$. Caring for elderly people with dementia means also taking on their social functions, besides keeping control of their immediate individual needs.

Most of the caregivers ( $>55 \%$ ) did not receive any kind of help, either formal or informal (Table 2), in accordance with findings from others studies about caregivers for dependent older adults ${ }^{(13-14)}$.

Regarding knowledge about dementia, most of the caregivers stated that they knew a sufficient amount about the disease, but only a minority had received formal training. As caregivers gained more knowledge of the disease they provided better quality of care ${ }^{(13,15-16)}$. When caregivers did not adequately understand the several possible manifestations of the dementing process, exhaustion and family conflicts are more probable for the caregiver ${ }^{(15)}$. These problems, in turn, may negatively reverberate in the quality of care of the demented elderly person receives and his/her well-being. Family caregivers need not only to receive education regarding the disease in question, but should also receive periodic home visits from health pro- fessionals in order to better deal with more idiosyncratic problems, like certain types of behaviors. This is a basic requisite for satisfying the needs of both demented elderly people and their caregivers ${ }^{(12)}$.

Families need to be able to rely on professional interdisciplinary teams, as those proposed by the Brazilian National Policy for the Elderly ${ }^{(17)}$. While some support from the family is expected, the State should have a major role in promoting, protecting and recovering the health of any elderly person. The family system functions as a reference nucleus. Nonetheless, it is essential that this nuclear system be supplemented by formal forms of support for the sake of better and uniform care for these demented elderly people - and their caregivers.

In the present study, many activities could be associated with physical tiredness and emotional fatigue, although there was not a statistically significant association between the stage of dementia and the items of overburdening (Table 4). Maybe this can be explained by the relatively small sample size of the present study. Among all the evaluated tasks, what was most physically tiring for the caregiver was assistance for bathing/hygiene.

The emotional overload upon caregivers may be considered a response to the personality and behavioral changes they observe in their loved ones. In this respect, caregivers reported the greatest emotional exhaustion when trying to control the behavior of the demented elderly individual (Table 4).

Alzheimer's disease was the most prevalent type of dementia in the study, followed by vascular dementia. These findings are in agreement with reports from most studies on the prevalence of dementia in Brazil(4).

The majority of demented elderly individuals were classified as mildly or severed demented. As expected, it was observed that the greater the degree of dementia, the greater the interference in the caregivers' lives tended to be (Table 4). As the disease progressed, individuals needed more and more supervision and care. They also reported that it was common to find family caregivers suffering from depression as a response to prolonged exposure to a situation of physical and emotional exhaustion that has the potential for generating stress ${ }^{(18)}$.

In comparing the mild and moderate stages of dementia, it was observed that physical and emotional exhaustion were often more prevalent in the mild than in the moderate stage of dementia. The meaning of this finding is not clear, but it may indicate that patients in the moderate stage of dementia might be more cooperative for their caregivers.

Moreover, a study carried out in Michigan (United States) showed that among 233 caregivers who were the spouses of demented elderly individuals, in the beginning of the dementia's development, the diagnosis has a strong 
impact on the elderly individual and his/her caregiver ${ }^{(19)}$. This may cause despair, sadness and distress. At the time of the medical diagnosis, families had difficulty learning how to deal with their beloved demented subject, and that this phenomenon was associated with fear and anxiety.

Some measures have emerged in relation to better care for the elderly population with dementia in Brazil, such as the supply of medication within the public network, which brought new possibilities for these families by contributing to lowering their treatments bills ${ }^{(17)}$. In addition to this, the creation of reference centers to provide specialized care for individuals with dementia has created the possibility for families to receive the necessary health attention

\section{CONCLUSION}

Findings of the research indicate that high levels of care may be associated with physical and emotional caregiver overburdening, even among early-stage demented elderly people (mainly emotional overburden). Brazilian caregivers receive insufficient assistance from both formal and informal social support systems.

However, criticisms for this work are needed. The study design implies the evaluation of a point in the disease period, which can have affected the accuracy of information, at times making the establishment of a confidential relationship between interviewer and interviewee impossible at the exact moment of the conversation. Thus, caregivers were not able to provide the interviewer information that represents their real feelings regarding care delivered to elderly individuals with dementia.

Evaluations by multidisciplinary teams, with the utilization of standardized instruments for making clinical, functional, social and cognitive diagnoses are necessary for these demented elderly subjects, mainly through longitudinal studies, to establish a confidence-relationship between interviewee and interviewer. Formal and informal planned support networks are also needed in order to draw up joint interventions between families and the different components of the public health system.

Current support networks are still insufficient for providing adequate support for Brazilian elderly people and their families. The need for comprehensive healthcare models for physically and mentally dependent elderly people should be voiced by the diverse sectors of society, with the intention of reaching the aims of the Brazilian National Policy for the Elderly and the Program of Family Healthcare proposals.

In conclusion, the present study made it possible to better understand the dimensions of the demands for caring for elderly people with dementia in Brazil. The Brazilian government action plan has provided the guidelines for comprehensively caring for the elderly, but the state and municipal health services, universities, non-governmental organizations and other networks need to become better organized in order to draw up formal and informal intervention proposals for elderly individuals and their family members.

\section{REFERENCES}

1. Kalache A, Veras RP, Ramos LR. Envelhecimento da população mundial: um desafio novo. Rev Saúde Pública. 1987;21(3):200-10.

2. Ramos LR. A explosão demográfica da terceira idade no Brasil: uma questão de saúde pública. Gerontologia. 1993;1(1):3-8.

3. World Health Organization (WHO). Ageing and Health Programme. Growing older. Staying well. Ageing and physical activity in everyday life. Geneva; 1998.

4. Vale FAC, Miranda SJC. Clinical and demographic features of patients with dementia attended in a tertiary out patient clinic. Arq Neuropsiquiatr. 2002;60(3A):549-52.

5. Lopes MA, Bottino CMC. Prevalência de demência em diversas regiões do mundo: análise dos estudos epidemiológicos de 1994 a 2000. Arq Neuropsiquiatr. 2002;60(1):61-9.

6. Papaléo Netto M, Klein EL. Demência I: epidemiologia, tipos e manifestações clinicas. In: Papaléo Netto M. Tratado de gerontologia. 2a ed. São Paulo: Atheneu; 2007. p. 323-38.

7. Campbell P, Wright J, Oyebode J, Job D, Crome P, Bentham P, et al. Determinants of burden in those who care for someone with dementia. Int J Geriatr Psychiatry. 2008;23(10):1078-85.
8. Pai MM, Soares MAL. Percepção do significado da função do cuidador por um grupo de enfermeiras e cuidadores: convergências e divergências em seus discursos. Rev Esc Enferm USP. 1999;33(3):231-5.

9. Montano MBMM, Ramos LR. Validade da versão em português da Clinical Dementia Rating. Rev Saúde Pública. 2005;39(6):912-7.

10. Duke University Center for the Study of Aging and Human Development. Multidimensional function assessment: the OARS methodology. Durham, NC; 1978.

11. Tobias MA, Lemos NF. A percepção do envelhecimento do cuidador diante do cuidado. Mundo Saúde. 2005;29(4):653-61.

12. Karsch UM. Idosos dependentes: famílias e cuidadores. Cad Saúde Pública. 2003:19(3):861-6.

13. Andrade LM, Costa MFM, Caetano JA, Soares E, Beserra EP. A problemática do cuidador familiar do portador de acidente vascular cerebral. Rev Esc Enferm USP. 2009;43(1):37-43.

14. Lopez J, Arrieta JL, Crespo M. Factors associated with the positive impact of caring for elderly and dependent relatives. Arch Geront Geriatr. 2005;41(1):81-94. 
15. Araújo MG, Lopes MSV, Machado MFA, Rocha EG. A família no cuidado ao portador de Doença de Alzheimer. Rev Técn Cient Enferm. 2004;2(8):95-100.

16. Bocchi SCM, Cano KCU, Baltieri L, Godoy DC, Spiri WC, Juliani $\mathrm{CMCM}$. Moving from reclusion to partial freedom: the experience of family caregivers for disabled elderly persons assisted in a day care center. Ciênc Saúde Coletiva [periódico na Internet]. 2007 [citado 2009 ago. 12]. Disponível em: http:/ /www.abrasco.org.br/cienciaesaudecoletiva/artigos/ artigo_int.php?id_artigo $=1027$
17. Brasil. Ministério da Previdência e Assistência Social. Plano de Ação Governamental Integrado para o Desenvolvimento Nacional do Idoso. Brasília; 1997.

18. Luzardo AR, Waldman BF. Atenção ao familiar cuidador do idoso com doença de Alzheimer. Acta Sci Health Sci. 2004;1(1):135-45.

19. Connell CM, Gallant MP. Spouse caregiver's attitudes toward obtaining a diagnosis of a Dementing illness. J Am Geriat Soc. 1996;44(8):1006-9. 